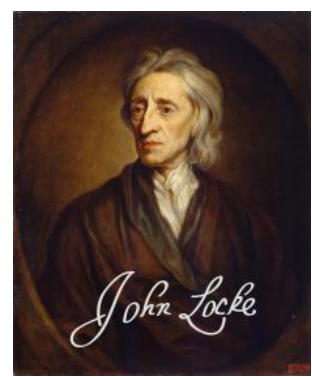

LOCKE STUDIES

Vol. 14

https://doi.org/10.5206/ls.2014.711 | ISSN: 1476-0290

Originally published: 2014

Published online: 19 FEBRUARY 2018

(C) Locke Studies, 2014

\title{
The Later Development of Lockean Abstraction
}

\author{
JONATHAN WALMSLEY (LONDON)
}

Recommended citation:

Walmsley, Jonathan. "The Later Development of Lockean Abstraction." Locke Studies 14 (2014): 59-84. https://doi.org/10.5206/ls.2014.711

For more information about this article:

https://ojs.lib.uwo.ca/index.php/locke/article/view/711

Locke Studies is published by The John Locke Society.

This is an open access article published under the terms of the Creative Commons AttributionNonCommercial-ShareAlike 4.0 International license, which permits use, distribution and reproduction in any medium, provided the original work is properly cited and shared under the original license. 


\title{
THE LATER DEVELOPMENT OF LOCKEAN ABSTRACTION
}

\author{
JONATHAN WALMSLEY
}

\section{Introduction}

Discussions of Locke's theory of abstraction generally confine themselves to the Essay. The only previous paper analysing the development of Locke's theory, by the present writer, ${ }^{1}$ dealt solely with drafts of the Essay - Locke's journals and the three drafts of the Essay, now known as Drafts A, B and C-the first two dating from 1671, and latter most likely from the first few months of $1686 .{ }^{2}$ This is a far from exhaustive survey of the subject in Locke's writings. There are numerous comments on universals and abstraction in Locke's philosophical works outside the Essay proper, including several extended discussions of the matter. Most of these were written after the publication of the Essay, providing a clear indication of Locke's mature views on abstraction. This paper will survey these materials to determine their import for interpretations of Locke's theory-most notably, whether they support a 'partial consideration' account as recently defended by Michael Ayers. ${ }^{3}$ Drawing on remarks made at different points in Locke's career, and addressing different subjects, the discussion is necessarily somewhat episodic, but it does, I believe, provide substantial further support for an interpretation of Locke's mature theory of abstraction as one of mental separation. In addition, this

1 Jonathan Walmsley, 'The Development of Lockean Abstraction', British Journal for the History of Philosophy 8 (2000): 395-418.

2 Jonathan Walmsley, 'Dating the 'Epitome' of the Essay' in Locke Studies 4 (2004): $205-22$, at 222.

3 Michael Ayers, 'Locke's Account of Abstract Ideas-Again', in Studies on Locke: Sources, Contemporaries, and Legacy: in Honour of G. A. J. Rogers, ed. Sarah Hutton and Paul Schuurman (Dordrecht, 2008), 59-73. 
historical evidence can provide further perspective on the writing of the Essay, highlighting how Locke's method of composition might well be the source of much of the difficulties that commentators find in the work.

\section{Abridgements of the Essay}

Until recently it appeared that the Draft $\mathrm{C}$ chapter 'Of Denomination \& Abstraction, ${ }^{4}$, written in the first few months of 1686 (as noted above) was the earliest statement of Locke's theory of abstraction in the context of a discussion of universals. Research by Hill and Milton, however, has shown that the 'Epitome' of the Essay ${ }^{5}$ antedates Draft $\mathrm{C}^{6}$ and further investigation has shown that a version of its first three books was most likely written circa April/May $1685 .^{7}$

The 'Epitome', as a précis of the Essay, includes analogues to the discussions in both Draft $\mathrm{C}$ and the published Essay. In particular, it discusses both the ideas of space and body, which, in Locke's Journal of 1676, had given rise to his remarks on partial consideration and abstraction, ${ }^{8}$ and includes a succinct statement of his views on abstraction in the context of general terms from

4 Draft C, II. xiii-currently unpublished, but to appear in Drafts for the Essay Concerning Human Understanding, vol. II. (Oxford, forthcoming).

5 Bodleian Library (henceforth 'Bodl.') MS Locke c. 28, ff. 52-82. Printed in P. King, The Life of John Locke (London, 1829), 362-98; repr. London 1830, 2 vols., ii, 231-93. Citations are from the 1830 edition.

6 James Hill and J. R. Milton, 'The Epitome (Abrégé) of Locke's Essay', in The Philosophy of John Locke: New Perspectives, ed, P. R. Anstey (London, 2003), 3-25.

7 Walmsley, 'Dating the 'Epitome", but see also Walmsley, 'Dating the 'Epitome' of the Essay: An Update', Locke Studies 12 (2012): 221-41, which confirms this dating, but shows that it was likely that Locke only sent a copy of Books I-III of the 'Epitome' at this point.

8 An Early Draft of Locke's Essay, together with Excerpts from his Journals, ed. R. I. Aaron and Jocelyn Gibb (New York, 1936), 77-80. Cf. Walmsley, 'Development', 41012. 
Book III. The discussion of the former sheds only a little light on Locke's views of the matter; Locke simply states that 'I shall not here set down what I have at large written, to show the clear distinction between the idea of body and space, which some have endeavoured to confound', his target clearly being Descartes. He elaborates that:

it shall suffice only to mention, that when distance is considered between any two things, abstract from any consideration of body filling up the interval, it may most properly be called space-when the distance is considered between the extremes of a solid body, it may fitly be called extension. The right application of these two terms, would, I hope, help us to avoid some confusion, which sometimes happens in discourses concerning body and space.

Here the word 'abstract' does feature in the discussion, and in the context of the discussion of the measurement of distance in pure space that prompted Locke's discussion of 'partial consideration' and its early identification with 'abstraction'. It may therefore betray a hint of the identification that Locke countenanced at this time, in the Journals and Draft $\mathrm{C}$, of 'partial consideration' with abstraction - but since 'partial consideration' is not mentioned, nor the subject dealt with in depth, it would not be clear to a reader that 'abstract' here meant anything other than 'separate'.

Locke's treatment of general terms in the 'Epitome' is more substantial. While the 'Epitome' has no analogue of the Essay's chapter 'Of Discerning, and other operations of the Mind', 10 which contained the Essay's first mention of abstraction, there is a summary of what would become Book III, Chapter 3, 'Of General Terms'. In this, the earliest extant statement of Lockean abstraction as a theory of universality of which I am aware, the discussion is brief but nonetheless clear about the process of the formation of general ideas:

9 King, Life of John Locke, ii, 240-41.

10 John Locke, An Essay concerning Human Understanding, ed. P. H. Nidditch (Oxford, 1975), II. xi. 1, 155-63. 
the general natures general terms stand for, are only general ideas, and ideas become general only by being abstracted from time and place and other particularities, that make them the representatives only of individuals, by which separation of some ideas which annexed to them make them particular, they are made capable of agreeing to several particulars. ${ }^{11}$

As later stated in III. iii. 6, abstraction is a process of 'separation' of those ideas which make something particular. ${ }^{12}$ Locke would later make similar remarks in the context of general ideas in Draft $\mathrm{C}$, remarks which there sat uneasily with his statements that abstraction and partial consideration were roughly equivalent. As noted in my earlier paper, it was this view of abstraction as 'separation' which seems to have prompted Locke to revise his views about the ideas of space and body, treating the former as a case of 'partial consideration', and reserving abstraction as mental separation for the formation of general ideas. ${ }^{13}$

The 'Epitome' served as the basis for Locke's pre-publication abridgement of the Essay in the volume 8 of the Bibliothèque Universelle \& Historique as the 'Extrait d'un Livre Anglois qui n'est pas encore publié, intitulé Essai Philosophique Concernant L'Entendement'. ${ }^{14}$ In places the 'Extrait' diverges significantly

11 King, Life of John Locke, ii, 258. Unfortunately, the passage regarding the triangle, which Berkeley made much of, has no equivalent in the 'Epitome', cf. op. cit., 284-86.

12 Draft C of the Essay contains only Books I and II, so has no direct equivalent of this passage.

13 Walmsley, 'Development', 412-17.

14 John Locke, 'Extrait d'un Livre Anglois qui n'est pas encore publié, intitulé Essai Philosophique Concernant L'Entendement, où l'on Montre Quelle est L'Étenduë de nos Connoissances Certaines, \& la Maniere Dont Nous Y Parvenons'. In Bibliothèque Universelle \& Historique 8 (1688), 49-142. As I pointed out in 2008, there were several editions of the Bibliothèque Universelle \& Historique (Jonathan Walmsley, 'Sydenham and the development of Locke's natural philosophy', British Journal for the History of Philosophy 16 (2008), 65-83, at n. 73). Professor J. R. Milton has subsequently provided a comprehensive investigation of these different editions (J. R. Milton, 'Locke's publications in the Bibliothèque Universelle et Historique', in British Journal for the 
from the English 'Epitome', ${ }^{15}$ but regarding general terms, the French translation (by Le Clerc, ${ }^{16}$ but doubtless checked by Locke) ${ }^{17}$ adds a little additional colour to Locke's English account:

les natures générales, dont les termes généraux sont les signes, ne sont que des idées générales; \& les idées deviennent générales seulement en faisant abstraction du temps, du lieu \& des autres particularitez, qui sont que ces signes représentent seulement des natures individuelles. Une idée formée de la sorte par abstraction, \& dégagée de tout ce qui la rendoit individuelle, est capable de représenter également plusieurs choses individuelles, entant que chacune d'elles a tout ce qui reste dans cette idée abstraite. ${ }^{18}$

Here, rather than use a direct translation of 'séparer', the text says that general ideas are formed through their being 'dégagée de tout ce qui la rendoit individuelle'. ${ }^{19}$ This French term means to extricate, liberate, release or free oneself from something, giving a clear sense that abstraction in this process creates general ideas that leave nothing tied to the ideas from which they were generated. The 'partial consideration' account, where the ideas must remain fully particular (though considered in a certain aspect), does not

History of Philosophy 19, (2011): 451-72).

15

Hill and Milton, 'The Epitome', 6-11.

16 Jean Le Clerc, 'Eloge de feu Mr. Locke', in Bibliothèque Choisie 6 (1705), 342411 , at $376-77$.

17 Locke made a correction to the French translation in the Errata of the Bibliothèque, and there are further corrections made in Locke's hand in all the extant copies of the offprint made from the 'Extrait', the Abregé D'un Ouvrage intitule Essai Philosophique touchant L'Entendement (Amsterdam, 1688) produced from the same type-setting. The details of Locke's care over the translation are presented in Walmsley, 'Dating the 'Epitome'...An Update', 238-39.

18

Locke, 'Extrait', 90.

19 Though it should be noted that Coste used 'séparer' in his translation of this passage for the French edition of the Essay. 
consist well with such a view. For Locke in the 'Extrait', general ideas were made by freeing or separating them from their concomitants in ideas of particulars. ${ }^{20}$

This pattern-omission of 'partial consideration', with abstraction as 'separation' - was repeated several years later in another summary of the Essay. In 1696 John Wynne published an abridgement he had developed with Locke's oversight and approval, ${ }^{21}$ and produced an updated edition as Locke updated the Essay. ${ }^{22}$ The abridged discussion of extension, space, and body in II. xiii gives clear statements of each, but does not mention the issue of how to conceive the parts of pure space which gave rise to the remarks on 'partial consideration'. Abstraction, on the other hand, is an important subject of discussion. Wynne includes Locke's discussion from II .xi, 'Of Discerning, and other Operations of the Mind':

20 Note, though, the translation of the passage on space in the 'Extrait'; Locke had said 'when distance is considered between any two things, abstract from any consideration of body filling up the interval, it may most properly be called space' (King, Life of John Locke, ii, 240). This was rendered in French as, 'lors que l'on considere par abstraction la distance qui est entre deux corps, sans avoir égard à ceux qui peuvent remplir cet intervalle, on le peut nommer proprement Espace' (Locke, 'Extrait d'un Livre', 61). Here abstraction is looking on as something 'without having regard' for something else - certainly not inconsistent with 'separation', but perhaps retaining a hint of 'partial consideration'.

21 Locke's side of the correspondence is now lost, but he appears to have seen and approved a version of the text as published. As Wynne put it in a letter of 25 June 1695, 'I have struck out that part of my Epistle, which left the disposal of it to you: And I think myself highly honoured and obliged that you are pleased to permit me to be so instrumental in the publishing of what, I hope will prove neither unacceptable nor unserviceable to the world' (The Correspondence of John Locke ed. E.S. De Beer (8 vols., Oxford, 1976-), v, 392. Locke suggested that Wynne publish with his own publisher, the Churchills, and later recommended Wynne to a place with the Earl of Pembroke (op. cit., $\mathrm{v}, 756-57$ ). Had Locke had any objections to the text of the Abridgement, he would have had no difficulty in having Wynne amend it.

22 A second edition of the Abridgement was produced in 1700 to reflect the changes made in the 4th edition of the Essay. References to the Abridgement are to the reprint of the 4th Edition, with an introduction by G. A. J. Rogers: John Wynne (ed.), An Abridgement of Mr Locke's Essay Concerning Human Understanding (London, 1731), repr. Bristol, 1990. 
Abstraction is another Operation of the Mind, whereby the Mind forms general Ideas from such as it receiv'd from particular Objects; which it does, by considering them, as they are in the Mind such Appearances separate from the Circumstances of real Existence, as Time, Place, \&c. These become general Representatives of all of the same Kind, and their Names applicable to whatever exists conformable to such abstract Ideas. Thus the Colour which I receive from Chalk, Snow, and Milk, is made a Representative of all of that Kind; and has a Name given it (Whiteness, ) which signifies the same Quality, wherever to be found or imagin'd. And thus Universals, both Ideas and Terms, are made. ${ }^{23}$

This was wholly consistent with the phrasing used in Wynne's version of III. iii, 'Of General Terms', where the process of abstraction was described as follows:

The next Thing to be considered, is how General Words come to be made. Words become general, by being made Signs of General Ideas: Ideas become general by separating from them the Circumstances of Time, Place, or any other Ideas that may determine them to this or that particular Existence. By this Way of Abstraction, they become capable of representing more Individuals than one; each of which having a Conformity to that Abstract Idea, is of that sort. ${ }^{24}$

Wynne then paraphrases Locke's unambiguous statement of this process in action:

It is evident that the first Ideas Children get are only particular, as of the Nurse, or Mother; and the Names they give them, are confined to these Individuals. Afterwards, observing that there are a great many other Things in the World that resemble them in Shape and other Qualities, they frame an Idea which they find those many Particulars do partake in; to that they give with others the Name Man, for Example: In this they make nothing new, but only leave out of the Complex Idea they had of Peter, James, Mary, \&c. that

\footnotetext{
23 Wynne, Abridgement, 53-54.

24 Op. cit., 163-64.
} 
which is peculiar to each, and retain only what is common to all. And thus they come to have a general Name, and a general Idea. ${ }^{25}$

Readers of Wynne's abridgement would have had no doubt about how general ideas were made - they were created by separating them from the other ideas in particulars that rendered them particular. A reader of this abridgement, intended as a quick introduction to Locke's work for university students, would have no inkling that a process of 'partial consideration' was any part of Locke's scheme of the understanding and its capacities. They would certainly not think it his process for the creation of general ideas - that was unequivocally one of mental separation.

\section{Remarks on Norris}

Locke had further occasion to discuss abstraction in relation to the views of others. A perceived personal slight in October 1692 set Locke to a critical review of the works of John Norris, ${ }^{26}$ and then to a broader consideration of the occasionalism of Malebranche. Norris had just published the second edition of his Christian Blessedness (London, 1692) which reprinted Norris's initial 1690 critique of Locke's work, 'Cursory Reflections upon a Book call'd An Essay concerning Human Understanding', with the additional 'A Brief Consideration of the Remarques made upon the foregoing Reflections by the Gentlemen of the Athenian Society, in the Supplement to the Third Volume, \&c. ${ }^{27}$ which presented Norris's response to criticism of his views. Locke used this, and Norris's Reason and Religion (London, 1689), as the basis for his critique

$$
25 \text { Op. cit., } 164 .
$$

26 Locke believed Norris had opened a letter from Damaris Masham which had been entrusted to Norris for transit. The incident is described in Roger Woolhouse, John Locke: A Biography (Cambridge, 2009), 316-18.

27 Norris was replying to The Supplement to the Third Volume of the Athenian Gazette (London, 1691), 2-3, a translation of the review of Norris's Cursory Reflections in the Bibliothèque Universelle et Historique 20, (1691), 65-72. 
in his 'Remarks upon some of Mr. Norris's Books, Wherein he asserts P. Malebranche's Opinion of our seeing all Things in God', first published in A Collection of Several Pieces of Mr. John Locke (London, 1720). ${ }^{28}$

Norris was concerned to argue that all of our perceptions were dependent on God, presenting a variety of considerations that he believed supported his position. In one such discussion, he claimed that the perception of particulars was, in some sense, dependent on a perception of all beings:

For we all find by certain experience that when we are minded to think of any particular thing, we first cast our eyes about upon all Beings, and then at last, adhere to the consideration of that Object, which we intended to think upon. $^{29}$

Locke's response to this statement of supposed fact will be discussed in more detail below. His premise stated, Norris continued:

But now all Beings cannot any other way be present to the mind, but because God is present to it, who in the Simplicity of his Being comprehends all beings. 30

Norris thus thought that it was impossible for us to think of anything without thinking of God. Norris then sought to press home his case by citing the related example of universals:

The same may be further confirm'd from the Perception of Universals. Which the mind could not well be supposed able to represent unless it saw all Beings included in One. For since every Created thing is an Individual,

28

John Locke, A Collection of Several Pieces of Mr. John Locke, ed. P. Desmaizeaux (London, 1720), 153-76. The text here is taken from the manuscript in the Bodleian Library, MS. Locke d. 3, pp. 89-109.

29

Norris, Reason and Religion, 196-97.

30

Op. cit., 197. 
no one can say that he perceives any thing Created, when he perceives, suppose, a Triangle in general. This well deserves to be consider'd. ${ }^{31}$

This line of argument in Norris gave Locke the chance to re-iterate his views about the nature of abstraction, first paraphrasing Norris's view:

The perception of Universals proves also that all beings are present to our mindes and that can be only because God is present, Because all created things are individuals. Resp: Are not all things that Exist Individuals? if so, then say not all created but all existing things are individuals, and if so, then the haveing any general Idea proves not, that we have all objects present to our mindes; but this is for want of considering wherein universality consists, which is only in representation abstracting from particulars; an Idea of a Circle of an Inch diameter will represent all the Circles of an Inch Diameter, where or whensoever existing and that by abstracting from time and place. And it will also represent all Circles of any bignesse by abstracting also from that particular bignesse, and by reteining only the relation of equidistance of the circumference from the centre in all the parts of it. ${ }^{32}$

The account here is consistent with that presented in the core of Locke's remarks about abstraction-serially removing what is particular to each and retaining only what is common to all-in this instance, time and place first, then size, etc.

Norris's association of God with the universal prompted further remarks on Locke's part. Norris claimed that we thought constantly on being in general:

Particular Beings we think of by intervals and with variety. But we always and uncessantly think of Being in general. And when we think of Particular Beings, we don't so much depart from Being in general, as confine and determin our minds to some certain Perfections of it...This I evidently experiment in myself [...therefore] Being in general is inseparably united to

31 Ibid.

32 MS Locke d. 3, pp. 92-4, cf. Locke, A Collection, 159-60. 
my mind, and intimately Present to it, as being always, and every where. ${ }^{33}$

Norris next identified God with 'Being in General', claiming that he has proved that 'Being in General is the same with God'. 34 On this ground he then claimed that 'If therefore Being in General be united to my Soul, then God is united to my Soul...And if God be so intimately united to my Soul, how can I otherwise conclude but that 'tis in him that I see all that I see?' ${ }^{35}$

This gave Locke the opportunity to reflect on the content of the idea of 'Being in General', which he considered an abstract idea:

To thinke of any thing is to contemplate that precise Idea. The Idea of Being in General is the Idea of Being abstracted from what ever may limit or determin it to any inferior species. So that he that thinks always of Being in general thinkes never of any particular species of Being unlesse he can thinke of it with and without precision at the same time. But if he means that he thinks of Being in General whenever he thinks of this or that particular Being or sort of Being, then it is certain he may always thinke of Being in General till he can finde out a way of thinking of nothing. ${ }^{36}$

This seems clear - to have the abstract idea of 'Being in general' is to think of it without 'whatever may limit or determin it to any inferior species'. Someone who thinks of the idea of being in general 'thinkes never of any particular species of Being'. This seems hard to reconcile with the claims made by those advancing a 'partial consideration' or 'selective attention' interpretation of abstraction. They claim that in forming abstract ideas, the thinker never departs from the particular, but focuses only on an aspect of that particular. Here Locke is emphatic that thinking of the more particular while simultaneously thinking of the more general is

33 Norris, Reason and Religion, 218.

34 Op. cit., 219.

35 Ibid.

36 MS Locke d. 3, p. 108, cf. Locke, A Collection, 175-76. 
little short of a contradiction-you could only do it if you could 'think of it with and without precision at the same time'. Locke seems to be clearly stating that it is impossible to think of the general while simultaneously retaining thought of the particular from which the general is derived. The 'partial consideration' interpretation seems untenable in the light of Locke's statements on this point.

Locke's does present an alternative interpretation of thinking of being in general-in which whenever you are thinking of something, you are thinking of 'some thing' and that might mean you are always thinking of some being or other, i.e. some being, in general; and you would only cease to think of some being, in general, when you cease thinking. But in such an instance, you are just thinking of lots of different beings, and not the abstract idea of being, so the theory of abstraction plays no substantive part.

Locke then returns to the consideration of abstract ideas, this time drawing contrast between his idea of God, and that of being in general:

Being in General is being abstracted from wisdom goodnesse power and any particular sort of Duration and I have as true an Idea of Being when these are excluded out of it, as when extension place solidity and Mobility are excluded out of my Idea. And therefore if Being in General and God be the same I have a true Idea of God when I exclude out of it power wisdom goodnesse and eternity. ${ }^{37}$

Abstract ideas exclude elements that determine them to particulars. And it seems, not just 'excluded from consideration' within the idea, but 'excluded out of my Idea' in toto. Again, this claim is difficult to square with a 'partial consideration' interpretation, where aspects of ideas may be unnoticed, but are supposed to remain part of the idea of the particular, while 'partial consideration' of other aspects forms the general idea. 'Excluded' is not ignored, overlooked or unheeded, but eliminated, removed

37 MS Locke d. 3, p. 108, cf. Locke, A Collection, 176. 
and omitted. 'Out of' is not alongside or thereabouts, it is not there, or elsewhere.

\section{The Examination of Malebranche}

Nor was such emphatic language an aberration on Locke's part. Locke continued his critique of Norris in more extended form by turning his attention to Norris's inspiration, in the 'Examination of P. Malebranche's Opinion of Seeing All things in God', written circa 1693, and first published in the Posthumous Works of Mr. John Locke (London, 1706). ${ }^{38}$ Norris had claimed that when thinking of a particular being, people first considered all beings, before alighting on that individual they wished to contemplate. Locke was less than convinced by this line of reasoning:

Nor do I thinke my Country Neighbours do so when they first wake in the morning, who I imagin do not finde it impossible to thinke of a lame horse they have, or their blighted corne till they have run over in their minde all beings that are, and then pitch on dapple; or else begin to thinke of Being in general which is Being abstracted from all its inferior Species, before they come to thinke of the Flie in their Sheep, or the tares in their corne. For I am apt to thinke that the greatest part of mankinde very seldom if ever at all thinke of Being in general i.e. abstracted from all its inferior Species and individuals. 39

Locke thinks the claim wholly implausible on its face, and at the same time echoes his previous statements that when you think of the abstract idea of being in general you think 'never of any particular species of Being'. A consistent tone is once again struck in a later comparison of the ideas of God and what Malebranche calls 'universal being': 40

38

John Locke, The Posthumous Works of Mr. John Locke (London, 1706), 141-213. The text here is taken from the manuscript in the Bodleian Library, MS Locke d. 3, pp. 186.

39 MS Locke d. 3, pp. 30-31, cf. Locke, Posthumous Works, 164-65.

40 At this point Locke was discussing Nicolas Malebranche, De La Recherche de la Vérité (Paris, 1678), III. II. vii, 205 (cf. The Library of John Locke, ed. John Harrison and 
I shall take notice of one or two things in it that confound me, and that is, that he calls God here the universal being, which must either signifie that being which conteins and is made up as one comprehensive aggregate of all the rest, in which sense the universe may be cald the universal being. Or else it must mean being in general which is nothing but the Idea of being abstracted from all inferior divisions of that general notion, and from all particular existence, but in neither of these senses can I conceive God to be the universal being since I cannot thinke the creatures either to be a part or a species of him. ${ }^{41}$

Being in general is 'abstracted from all inferior divisions of that general notion, and from all particular existence'. These remarks are consistent with those in the comments on Norris - the abstract idea should have no trace of the particulars from which it derives, a requirement inconsistent with the 'partial consideration' interpretation.

\section{Stillingfleet}

Further comments touching on Locke's account of abstraction can be found in his dispute with Edward Stillingfleet. Stillingfleet was concerned to defend the notion of the Trinity against what he saw to be the threat posed by Locke's 'way of Ideas', and in doing so touched questions of 'personhood', and the 'nature' of a man, concepts he took to be more fundamental than mere compounds of ideas derived from sensation and reflection. Locke attempted to parse Stillingfleet's arguments:

I must then confess to your Lordship, 1. That I do not clearly understand whether your Lordship, in these two Paragraphs, speaks of Nature, as standing for Essential Properties; or of Nature, as standing for Substance; and yet it is of great moment in the Case, because your Lordship allows,

Peter Laslett (Oxford, 1971), item 1883). Malebranche there states that 'On ne peut concevoir que quelque chose de créé puisse représenter l'infini; que l'être sans restriction, l'être immense, l'être universel puisse être apperçû par une idée, c'est-à-dire par un être particulier, par un être différent de l'être universel \& infini...Ainsi il est nécessaire de dire, que l'on connoît Dieu par lui-même'.

41 MS Locke d. 3, p. 61, cf. Locke, Posthumous Works, 190. 
That the Notion of Nature in the former of these Senses, may be had from Sensation and Reflection; but of Nature in the latter Sense, your Lordship says, It properly belongs to Reason, and not mere Ideas. 2. Your Lordships saying in the first of these Paragraphs, That the Nature of Man, as in Peter, is distinct from the same Nature as it is in James and John: And in the second of them, That however the SAME Nature may be in different Individuals, yet the Nature it self remains ONE AND THE SAME, does not give me so clear and distinct an Apprehension concerning Nature, that I know which, in your Lordships Opinion, I ought to think, either that one and the same Nature is in Peter and John; or that a Nature distinct from that in John, is in Peter: And the Reason is, because I cannot, in my way by Ideas, well put together one and the same and distinct. ${ }^{42}$

This gave Locke occasion to state his view of what it was to have the nature of 'man', an instance, in his view, of the conformity of an individual to the abstract idea of 'man':

a Collection of several Ideas, combined into one complex, abstract Idea, which when they are found united in any Individual existing, though joined in that Existence with several other Ideas, that individual or particular Being is truly said to have the Nature of a Man, or the Nature of a Man to be in him; for as much as all these simple Ideas are found united in him, which answer the complex, abstract Idea, to which the specifick name Man is given by any one: which abstract, specifick Idea, he keeps the same, when he applies the specifick Name, standing for it, to distinct Individuals. ${ }^{43}$

Here, as in his earlier statement in Draft B, regarding the idea of blue being but 'one single numericall thing', ${ }^{44}$ Locke is clear that the general idea is a 'specifick Idea, [which] he keeps the same, when he applies the specifick Name standing for it, to distinct

42 John Locke, A Letter to the Right Reverend Edward Lord Bishop of Worcester, Concerning some Passages relating to Mr. Locke's Essay of humane Understanding: in a late Discourse of his Lordships, in Vindication of the Trinity, (London, 1697), 163-64.

43 Op. cit., 165.

44

John Locke, Drafts for the Essay Concerning Human Understanding, and other Philosophical Writings, ed. P. H. Nidditch and G. A. J. Rogers, (Oxford, 1990) (henceforth Draft A or B), §59, 161-62. 
Individuals'. There is, it seems, one abstract idea of 'man' (as there is one word 'man') which, once created, is applied serially to individual men. Indeed, Locke usefully elucidates this very point:

i.e. no Body changes his Idea of a Man, when he says Peter is a Man, from that Idea which he makes the name Man to stand for, when he calls John a Man. ${ }^{45}$

This seems difficult to square with the 'partial consideration' interpretation of Locke's theory of abstraction. There, someone created an idea of man in general by considering just some aspects of different men, and could do so on any occasion on which an individual was encountered. On the partial consideration interpretation, then, you were considering a different idea when considering the idea of Peter as a source of the general idea of 'man' than when considering John, since you were considering aspects of ideas of different individuals. To be sure, you were considering the same aspects in the different individual ideas, but according to the proponents of the 'partial consideration' account, any individual idea will suffice to conceive of the universals under which this and other similar individuals could be ranked. In his debate with Stillingfleet, Locke explicitly denies that this is possible - the abstract idea of 'man' is a single unchanging object of thought that is brought to bear in any ranking of Peter and John under the universal. Broadly speaking, it seems here that, once made, the specific general idea of 'man' 'keeps the same' and is applied to all individual men indifferently and without variation in any instance where individual men need to be ranked under a sort or kind. The 'partial consideration' account is inconsistent with this statement on Locke's part.

\section{The Elements of Natural Philosophy}

Locke also had occasion to mention abstraction in the Elements of Natural Philosophy, first published in the 1720 Collection of

45 Locke, A Letter to the... Bishop of Worcester, 165. 
Several Pieces mentioned above, ${ }^{46}$ most likely written for Frank Masham, certainly not earlier than $1698{ }^{47}$ The final chapter of the work provided an account ' $O f$ the Understanding of Man', a highly simplified account of Locke's views on the matter. Locke commences with a discussion of perception, and its giving rise to simple ideas of sensation or reflection, which can then be compounded into complex ideas of individual objects. Locke then continues:

The next thing the Understanding doth in its progress to knowledge, is to abstract its Ideas, by which Abstraction they are made general.

A general Idea is an Idea in the mind, consider'd there as separated from time and place; and so capable to represent any particular being that is conformable to it. ${ }^{48}$

Though the account is simplified to perhaps the point of absurdity (surely time and place alone do not suffice to make things particular), the general tenor of the theory in this, the last account Locke gave of abstraction that I am aware of, is consistent with every other mature account he gave of abstraction - it is a theory of mental separation.

\section{Locke's Theory of Abstraction in Historical Perspective}

Reviewing the later development of Locke's theory of abstraction we can note that none of Locke's later writings on this subject are naturally read as out-and-out statements of a 'partial consideration' theory. Indeed, all seem straightforwardly consonant with a 'separation' interpretation. A commentator sympathetic to the partial consideration interpretation might note that Locke was not always the clearest of writers, and concede that one, or perhaps

${ }^{46}$ Locke, A Collection, 177-230.

47 J. R. Milton, 'Locke and the Elements of Natural Philosophy: Some Problems of Attribution', Intellectual History Review 22, (2012): 199-219, at 201-2.

${ }^{48}$ Locke, A Collection, 227. 
two, of these examples could perhaps be rendered in such a way as to fit with a 'partial consideration' reading. But the commentator's credulity would be stretched to breaking point if required to suppose that Locke did not mean what he appears to say in more than half a dozen places written at different times on different topics to different ends.

Further, the language of several of the examples seems to be directly inconsistent with the tenets of a 'partial consideration' interpretation. Locke says three times that in forming an abstract idea of Being from the idea of God, several parts of the initial idea are 'excluded out of it'. It is more than just difficult to read this as saying, for example, 'focusing one's attention on the idea of being and not on those other components of the idea of God'- the basic meaning of 'exclude' and 'out of' as commonly understood preclude such a reading. If any reader remained unconvinced by Locke's words on this point, there would be little more I could do to persuade them.

In sum, then, the later development of Locke's theory of abstraction seems consistent with that in its earlier phases-while Locke might have toyed with a 'partial consideration' theory during the writing of the Essay, by the time the work was published (and in its published abridgements) he adhered to a separation theory - as was clearly stated at every point in that work whenever Locke directly addressed himself to this subject in the several editions of it. We can now see that at every later point in which Locke wrote on abstraction he presented further instances and examples most naturally read as part of a 'separation' account. Such evidence is consistent with the hypothesis that Locke's mature (and considered) theory of abstraction was one of separation.

Having considered its drafts, the Essay proper, and Locke's subsequent writings we might now step back to take a more comprehensive view of the subject. In correspondence, Michael Ayers has stated that it is the responsibility of any exegete 'to look for a consistent understanding of all that Locke put into the Essay'. It must be said that Locke does not make this easy. As noted in my 
preceding article on this subject, ${ }^{49}$ in II. xiii. 11 some ideas require others for their existence and conception. Yet, as shown in that article, III. x. 15 seems to suggest that it is possible to create 'Conceptions' that cannot exist in nature. Equally, in III. vi. 16, in the chapter immediately following his account of General Terms, Locke considers the idea of colour and other qualities:

There is nothing that can be left out of the Idea of White and Red, to make them agree in one common appearance, and so have one general name; as Rationality being left out of the complex Idea of Man, makes it agree with Brute, in the more general Idea and name of Animal. And therefore when to avoid unpleasant enumerations, Men would comprehend both White and Red, and several other such simple Ideas, under one general name; they have been fain to do it by a Word, which denotes only the way they get into the Mind. For when White, Red, and Yellow, are all comprehended under the Genus or name Colour, it signifies no more, but such Ideas, as are produced in the Mind only by the Sight, and have entrance only through the Eyes. And when they would frame yet a more general term, to comprehend both Colours and Sounds, and the like simple Ideas, they do it by a Word, that signifies all such as come into the Mind only by one Sense: And so the general term Quality, in its ordinary acceptation, comprehends Colours, Sounds, Tastes, Smells, and tangible Qualities, with distinction from Extension, Number, Motion, Pleasure, and Pain, which make impressions on the Mind, and introduce their Ideas by more Senses than one. ${ }^{50}$

It is somewhat worrying that Locke did not mention this rather significant exception to his account of how general ideas were formed in III. iii. Nor is it particularly clear how Locke could square this with his comment in III. iii. 9 that 'he that thinks general Natures or Notions, are any thing else but such abstract and partial Ideas of more complex ones, taken at first from particular Existences, will, I fear, be at a loss where to find them, ${ }^{51}$ The

49 Jonathan Walmsley, 'Locke, Ayers, and Abstraction', Locke Studies 14, (2014): $29-58$, at 53.

50 Essay, III. iv. 16, 427-28. I am grateful to Professor J. R. Milton for this example.

51 Essay, III. iii. 9, 412. 
reader had only to continue a very few pages to find Locke's counter-example to his own assertion.

In the same correspondence, Ayers provided another interesting example of Locke's inconstancy, citing Locke's description of key ideas from both sensation and reflection:

Existence and Unity, are two other Ideas, that are suggested to the Understanding, by every Object without, and every Idea within. When Ideas are in our Minds, we consider them as being actually there, as well as we consider things to be actually without us; which is, that they exist, or have Existence: And whatever we can consider as one thing, whether a real Being, or Idea, suggests to the Understanding, the Idea of Unity. ${ }^{52}$

Such comments are not easy to reconcile with Locke's statement in III. iii. 9 that abstraction by mental separation is how we form even the most general ideas:

And not to dwell longer upon this particular, so evident in it self, by the same way the Mind proceeds to Body, Substance, and at last to Being, Thing, and such universal terms, which stand for any of our Ideas whatsoever...In all which, this is constant and unvariable, That every more general term, stands for such an Idea, as is but a part of any of those contained under it. ${ }^{53}$

Ayers is right that the remarks in II. vii. 7 speak more to 'consideration' than 'separation'. They are therefore very hard to square with those in III .iii. 9. It is thus difficult 'to look for a consistent understanding of all that Locke put into the Essay'.

This example, however, may provide a clue as to how we could approach inconsistencies. As noted in my previous paper on the development of Lockean abstraction, Locke's views on abstraction underwent significant change in the different drafts of the Essay. His remarks in II. vii. 7 are strikingly redolent of some of his

\footnotetext{
52 Essay, II. vii. 7, 131.

53 Essay, III. iii. 9, 412.
} 
earliest remarks on universals. In Draft A, Locke put forward the theory that we only use general words to stand for many different particular objects:

The minde for the conveniency of marhsalling its owne Ideas, recording its owne thoughts and observations \& signifying them to others being apt to make general words to expresse a great number of particular things, doth for the same reason make some universal words for all its Ideas which shall equally belong to each of them such are Entity Being Something Existing and that the notion of Being is but coadequate to the particular Ideas we have gatherd from sense or sensation \& can be extended noe farther then they \& soe is noe new notion nor an innate Idea but a general appellation of those particular ones that we have got by observation. ${ }^{54}$

Equally, in Draft A, Locke described the 'notion of one' as something 'suggested by every object of sense' through 'the consideration of that thing alone'. ${ }^{55}$ The sentiments expressed in II. vii. 7 closely mirror those in the very earliest drafts of the Essay and may well have descended without major modification from an earlier, less sophisticated theory, leaving a misleading impression of Locke's mature views.

Another example is provided in Locke's correspondence with Stillingfleet. Stillingfleet, not unreasonably, pointed out that Locke's account of substance in II. xxxiii. 1, where we suppose an idea of substance, did not seem to sit well with his broader theory of how general ideas are formed:

But how comes the general Idea of Substance, to be framed in our minds? Is this by Abstracting and inlarging simple Ideas? No, but it is by a Complication of many simple Ideas together: because not imagining how these simple Ideas can subsist by themselves, we accustom ourselves to suppose some Substratum wherein they do subsist, and from which they do result, which therefore we call Substance. And is this all indeed, that is to be

\footnotetext{
54 Draft A, §8, 19.

55 Draft A, §12, 24.
} 
said for the being of Substance, that we accustom ourselves to suppose a Substratum? ${ }^{56}$

Stillingfleet seems to have a point-you would think that you would need to employ abstraction in forming this general idea, since it is one of the most general. And, indeed, when addressing this criticism, Locke was uncharacteristically ready to concede that he did not express himself clearly. Concerning the charge 'That I make the general Idea of Substance to be framed, not by abstracting and enlarging simple Ideas, but by a Complication of many simple Ideas together', Locke noted

That I say in more Places than one, and particularly those above quoted, where ex professo I treat of Abstraction and general Ideas, That they are all made by abstracting, and therefore could not be understood to mean, that that of Substance was made any other way, however my Pen might have slipt, or the negligence of Expression, where I might have something else than the general Idea of Substance in view, might make me seem to say so. ${ }^{57}$

Locke then went on to clarify that II. xxxiii. 1 dealt primarily with the complex ideas of substances rather than the idea substance in general-though even then, Locke's account of abstraction as separation makes no special provision for the supposition of an idea of substance in general that Locke makes the keystone of his theory. Simply put, despite Locke's protestations to the contrary, Locke's account of the idea of substance in general does not readily consist with his account of abstraction. Taking an historical view of the matter, we can well see why it does not. Locke's account of substance originally appears in the very first section of Draft A of the Essay - one of his earliest sustained philosophical

56 Edward Stillingfleet, A Discourse in Vindication of the Doctrine of the Trinity: With an Answer to the Late Socinian Objections against it from Scripture, Antiquity and Reason (London, 1697), 236.

57 Locke, A Letter to the... Bishop of Worcester, 28-29. 
reflections. ${ }^{58}$ Moreover, this account descended largely unchanged into the published Essay. ${ }^{59}$ As noted in my earlier paper, in Draft A, Locke held there were no universal ideas and had no theory of abstraction to speak of. ${ }^{60}$ Locke's mature account of universals and abstraction was developed several years after his account of substance and we can, for that reason, see why they seem largely unrelated. Stillingfleet was right to point out their divergence, and Locke's only response was to insist that they really were the same, whatever other impression his actual writings might give.

We may note, then, that though it is clear what Locke's mature theory of abstraction and the formation of general ideas was, there remain significant challenges to creating an entirely consistent reading of the theory presented in the Essay-put bluntly, Locke contradicts himself, he is inconsistent, and has not fully considered the consequences of all of his statements. Locke noted that the Essay was 'written by incoherent parcels; and after long intervals of neglect, resum'd again' . 11 The drawn-out process of the Essay's composition may have created a work that is less than completely consistent. ${ }^{62}$ It may therefore be impossible to create an interpretation that gives us a completely consistent understanding 'of all that Locke put into the Essay'.

\section{Interpreting the Essay}

Should we then give up the search for a fully intelligible interpretation of Locke's views on this subject? I would argue that it is Ayers's original work on the subject which should direct us in

58

Draft A, $§ 1,1$.

59 Walmsley, 'Dating the 'Epitome", 24-26 and 36-37.

60

Walmsley, 'Development', 398-405.

61

Essay, 'The Epistle to the Reader', 7.

62 A history of the writing of the Essay is given in Jonathan Walmsley, 'An Essay concerning Human Understanding' in The Continuum Companion to Locke, ed. S.-J. Savonius-Wroth, Paul Schuurman, and Jonathan Walmsley (London, 2010), 234-49. 
this regard. Ayers's philosophical acumen was second to none in emphasising the passages in II. xiii on the partial consideration of space, subsequently highlighting their deep historical relevance to the debate on abstraction. There were significant differences in Locke's account of universals throughout the Essay's development - different periods presented different views. Locke first held that there were no universal ideas. He then stated that there were, but gave no account of their genesis. Later accounts suggested a 'partial consideration' account, but this was soon competing with an avowed 'separation' account of abstraction. The difference between Draft $\mathrm{C}$ and the Essay shows Locke clearly understood the difference between 'partial consideration' and 'separation', amending his text at this key juncture to separate out his descriptions of these different mental processes to indicate their distinct spheres of application. Whenever Locke presented his theory of abstraction in any published version of the Essay he clearly stated that it was one of separation, creating a 'partial' and 'incomplete' idea, with a specific name that stood for all of that kind. Unfortunately, other descriptions of universals in the published Essay were less precise. This was sometimes because they were unrevised vestiges of earlier drafts. Sometimes, however, it was also because Locke was less precise than we might like, and sometimes because he may have felt that an exception was required (as seems clear in the case of 'colour' noted above). But none of this detracts from the central fact that every time Locke talked about abstraction as his theory of universals, he gave a 'separation', not a 'partial consideration', account. That we now find that all of Locke's writings composed after the first edition of the Essay take the same line strongly supports such an interpretation. Indeed, Locke's discussion of abstraction after the publication of the Essay shows that key elements of a partial consideration interpretation are incompatible with Locke's stated views; you can't think of the more and less general at the same time, and an abstract idea is the same particular object of thought applied in different instances, not different objects of thought considered in the same way at different times. It is impossible to 
avoid the conclusion that Locke's mature theory of abstraction was one of the separation of parts of ideas to form images that are radically (and impossibly) incomplete.

With this in mind, we can look again at Ayers's adjuration 'to look for a consistent understanding of all that Locke put into the Essay'. Historians of philosophy should certainly look to develop the most charitable interpretation of their subjects' work, and consistency is certainly a virtue in any philosophical theory; but historians must recognise the evidence of changes of opinion and the character of the work and writer in question. Given the cumulative nature of the Essay's composition, Locke's changing views, and his irregular approach to revision, it is impossible to create a consistent view of all that Locke put into the Essay on the subject of abstraction. But it is certainly possible to determine Locke's considered view of the matter. His mature theory was one of separation - every time he came to write directly on subject of abstraction in the published Essay, its abridgements and any later philosophical work, he made it clear that this was how he believed general ideas were created. So while you cannot create a consistent interpretation of everything in the Essay on this subject because of the way it was written, it is equally clear what Locke's considered view on the matter was.

Indeed, Locke himself recognised that his changes of mind were not always updated throughout the Essay as he continued to add to it. This is evident in his treatment of the 'qualities' of bodies. It is possible to trace Locke's evolution from a scholastic account of sensible qualities existing in both mind and object in Draft A, to his settled view in the Essay that 'Ideas [are] in the Mind, Qualities in Bodies'. ${ }^{63}$ Unfortunately, however, Locke did not systematically revise all his remarks in the later drafts to render his writing completely consistent. So, in the published Essay he felt that he had to remind the reader regarding ideas that if I speak of

63 Essay, II. viii. 7-8, 134 (section heading). Cf. Jonathan Walmsley, 'Locke's Natural Philosophy in Draft A of the Essay', Journal of the History of Ideas 65, (2004): 15-37, at 28-31 and 34-35. 
sometimes, as in the things themselves, I would be understood to mean those Qualities in the Objects which produce them in us', ${ }^{64}$

If we seek to understand Locke's works by consulting Locke himself, we should not necessarily seek a consistent understanding of all that Locke says in the Essay - if the cost is distorting Locke's obvious intentions and meaning beyond recognition. Instead, where possible, we should seek Locke's considered philosophical position. Taking an historical perspective, and separating out different strata from different compositional periods, then balancing exceptions and infelicities against repeated statements of intent, we might have a much better chance of determining Locke's mature and considered views on a given philosophical topic. ${ }^{65}$ This may not make Locke's considered view on any subject correct, and it may not make it consistent with other key elements of his philosophical outlook, but it can help make clear what Locke at least thought he was saying when he published the Essay.

London $^{66}$

64

Essay, II. viii. 8, 134.

65 For example, despite a helpful review of Drafts A and B, Peter Anstey, discussing Locke's views on mathematics frankly admits that 'Locke's views on mathematical knowledge in the Essay have proven to be enormously difficult to interpret in a consistent way. In all honesty, I am not confident that a fully consistent interpretation of Locke's view is possible' (idem., John Locke and Natural Philosophy (Oxford, 2011), 118). A more thoroughgoing historical approach might help to identify different strata of Locke's views, to separate earlier and later positions and to determine if Locke himself ever thought he had reached a considered point of view on the matter in the Essay.

66 I would like to thank Michael Ayers for the correspondence we have had on this subject and these papers, J. R. Milton for his comments on previous versions, and the anonymous referees for several helpful comments. 